\title{
High-strength concrete technology for manufacturing reinforced concrete sleepers from prestressed reinforced concrete
}

\author{
Urinbek Turgunbaev ${ }^{*}$, and Movluda Umirova \\ Tashkent State Transport University, Tashkent, Uzbekistan
}

\begin{abstract}
The properties of concrete with complex chemical additives to improve the technology for the production of sleepers from prestressed concrete are discussed in the article. With the use of complex chemical additives under heat-moisture processing, at a temperature of $40^{\circ} \mathrm{C}$, there was no decrease in the strength of the cement stone and sufficient strength at the initial stage of the curing period, $44.7 \mathrm{MPa}$; concrete strength was determined with the addition of Glenium $27 \mathrm{~S}-1.0 \%$ and the hardening accelerator Master X -Seed $100-1.2 \%$. Thus, the use of complex chemical additives makes it possible to solve the problem of achieving the necessary early high strength of concrete to implement low-temperature technology in the production of reinforced concrete sleepers.
\end{abstract}

\section{Introduction}

One of the urgent problems of modern construction is the creation and improvement of technology to produce sleepers from prestressed reinforced concrete.

Currently, in concrete technology, the main tasks are to increase the strength and durability of concrete; to reduce labor and energy costs associated with the manufacture of concrete and reinforced concrete structures [9-15].

To solve these problems, various technologies are used, associated with the introduction of various chemical additives that improve the properties of concrete [2-11]. Currently, the most popular are complex additives that increase the strength of concrete and its water resistance, frost resistance, and improve other properties of the concrete mixture. In addition, some additives increase the manufacturability of the production of concrete products. However, while increasing the final strength of concrete in the late periods of hardening, many additives do not allow obtaining high concrete strength in the early periods of hardening.

To accelerate the curing of concrete, heat-moisture treatment is often used in steaming chambers at a relative moisture content of $100 \%$ and a temperature of $+80 \ldots 95^{\circ} \mathrm{C}$. However, at such temperatures of heat treatment in the initial period, significant thermal stresses arise in hardening concrete, exceeding its strength and causing the crack formation, leading to a decrease in the final strength and durability of the structures being

*Corresponding author: urinbekdj@mail.ru 
manufactured. Therefore, another way to improve the quality and to increase the durability of concrete products is to change their production technology $[6,17,18$.

Like 50 years ago, the technology for the production of reinforced concrete sleepers is based on the heat-and-moisture treatment of products at a temperature of $80^{\circ} \mathrm{C}$, which allows for a quick set of early concrete transfer strength. At the same time, this technology has several disadvantages associated with the deterioration of the cement stone structure and a decrease in the final strength and frost resistance of concrete, high-energy consumption, weakening of the contact zone of the cement stone with pre-stressed reinforcement and polymer embedded elements [1].

Scientific achievements in the field of directed formation of the structure and properties of concrete allow today to formulate ways to improve the technology for the production of sleepers from prestressed reinforced concrete [2]. The most promising of them is the introduction of a non-heating or low-heating technology; with the use of chemical additives of polyfunctional action, it is possible to have a significant effect on the properties of concrete mixture and concrete since this direction requires the least investment and can quickly give a tangible economic effect due to energy savings.

The appearance of additives-superplasticizers, and, in the last decade, hyper plasticizer, revolutionized the science of concrete, allowed the introduction of the term "modified concrete" $[4,16,19,20]$. The development of scientific ideas about concrete in recent decades, especially using modifiers of its structure, allows today to provide early high strength with no-steam or low-heating technology $[3,12,13]$. By reducing water consumption up to $30-35 \%$ while ensuring equal mobility of the concrete mixture, new technologies substantially increase the strength of concrete and save cement.

It is necessary to decide on the terminology about the production technology of sleepers. Since at present the production of reinforced concrete sleepers is performed on a twelvehour cycle, to maintain the existing technology and reuse of forms, we have proposed the following definitions:

No-steam or no-heat technology is a technology that ensures the transfer strength of concrete at the age of 12 hours at a temperature no higher than 30 degrees;

Low-temperature (low-heat) technology is a technology that provides the transfer strength of concrete at the age of 12 hours at a temperature no higher than 40 degrees.

To increase the strength of concrete in the initial period of hardening, a technology for concrete production for prestressed reinforced concrete sleepers was developed. It consists of the preparation of concretes with a complex additive Glenium $27 \mathrm{~S}$ in an amount of 0.5 $\ldots 1.0 \%$, the hardening accelerator Master X-Seed $100-1.2 \%$ of the cement mass and heat treatment of concrete in a soft steaming mode. The concrete and reinforced concrete products are manufactured according to the following technology: a complex additive Glenium $27 \mathrm{~S}$ is introduced into the concrete mixture, which includes a binder, fine and coarse aggregates and mixing water in an amount of $0.5 \ldots 1.0 \%$; hardening accelerator Master X-Seed $100-1,2 \%$ of the mass of cement; the prepared mixture is placed in molds, then it is held at a temperature of $+18-20^{\circ} \mathrm{C}$ for $0.5 \ldots 3.5$ hours, then it is steamed at a temperature of $+40^{\circ} \mathrm{C}$ according to the following mode of hours $(1 \ldots 3)+(2 \ldots 6)+(1 \ldots$ 3).

Glenium $27 \mathrm{~S}$ and hardening accelerator Master X-Seed 100 were used as additives. The effect of these additives on the strength properties of cement-sand compositions and concretes was studied.

\section{Materials and Methods}

Portland cement M 400-D0 from OAO Akhangarantsement was used as a binder for concrete. 
Chemical and mineral compositions of Portland cement clinker are: $\mathrm{wt} \%$ : $\mathrm{SiO}_{2}$ of 21,$66 ; \mathrm{CaO}$ of 64,$95 ; \mathrm{Al}_{2} \mathrm{O}_{3}$ of 5,$01 ; \mathrm{Fe}_{2} \mathrm{O}_{3}$ of 4,$01 ; \mathrm{MgO}$ of 3,$42 ; \mathrm{SO}_{3}$ of 0,$40 ; \mathrm{R}_{2} \mathrm{O}$ of 0,46 ; $\mathrm{C}_{2} \mathrm{~S}$ of 16,$33 ; \mathrm{C}_{3} \mathrm{~S}$ of 60,$22 ; \mathrm{C}_{3} \mathrm{~A}$ of 6,48 and $\mathrm{C}_{4} \mathrm{AF}$ of 12,19 .

According to its physical and mechanical parameters (Tables 1 and 2), the Portland cement taken for the study meets the standard requirements [5].

Table 1. Physical properties of Portland cement

\begin{tabular}{|c|c|c|c|c|c|}
\hline & \multirow{2}{*}{$\begin{array}{c}\text { Average } \\
\text { Tensity }\end{array}$} & $\begin{array}{c}\text { True } \\
\text { density }\end{array}$ & \multicolumn{2}{|c|}{ Fineness of grinding } & Normal \\
\cline { 4 - 5 } & $\mathrm{g} / \mathrm{cm} 3$ & $\mathrm{~S} / \mathrm{cm} 3$ & $\begin{array}{c}\text { Specific } \\
\text { surface } \\
\text { area } \\
\mathrm{cm} 2 / \mathrm{g}\end{array}$ & $\begin{array}{c}\text { Sieve } \\
\text { residue } \\
0,08 \%\end{array}$ & $\begin{array}{c}\text { consistency } \\
\%\end{array}$ \\
\hline $\begin{array}{c}\text { Portland cement Akhangaran } \\
\text { grade 400 D0 }\end{array}$ & 1.21 & 3.2 & 3000 & 8.5 & 26.0 \\
\hline $\begin{array}{c}\text { Portland cement Akhangaran } \\
\text { grade 400 D20 }\end{array}$ & 1.20 & 3.18 & 3000 & 8.2 & 28.0 \\
\hline
\end{tabular}

Table 2. Physical and mechanical properties of Portland cement

\begin{tabular}{|c|c|c|c|c|c|}
\hline Type of cement & \multicolumn{2}{|c|}{$\begin{array}{c}\text { Setting time } \\
\text { h-min }\end{array}$} & \multicolumn{2}{c|}{$\begin{array}{c}\text { Ultimate strength after 28 } \\
\text { days of hardening, MPa }\end{array}$} & \multirow{2}{*}{$\begin{array}{c}\text { Volume } \\
\text { uniformity }\end{array}$} \\
\cline { 2 - 5 } & beginning & end & bending & compression & \\
\hline $\begin{array}{c}\text { Portland cement } \\
\text { Akhangaran grade 400 } \\
\text { D0 }\end{array}$ & $1-10$ & $6-20$ & 5,80 & 41,80 & withstand \\
\hline $\begin{array}{c}\text { Portland cement } \\
\text { Akhangaran grade 400 } \\
\text { D20 }\end{array}$ & $1-20$ & $6-40$ & 5,60 & 40,6 & withstand \\
\hline
\end{tabular}

River quartz sand with a size modulus of 1.81 and an average density of $\sim 2000 \mathrm{~kg} / \mathrm{m}^{3}$ served as a fine concrete aggregate. The content of foreign particles (clay, dust, and silt) did not exceed $0.15 \%$. The sand used met the standard requirements [5]. The graph of sand sifting is shown in Figure 1.

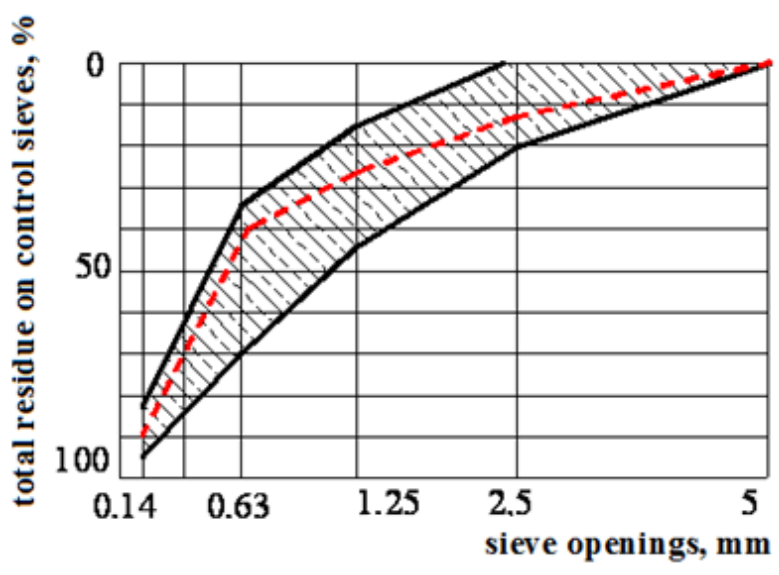

Fig. 1. Graph of sand sifting

Crushed stone of 5-10 and 10-20 mm fractions, with an average density of $1400 \mathrm{~kg} / \mathrm{m}^{3}$ was used as a coarse concrete aggregate. The content of clayey, silty and dusty impurities did not exceed $0.4 \%$.

The graph of crushed stone sifting is shown in Figure 2. 


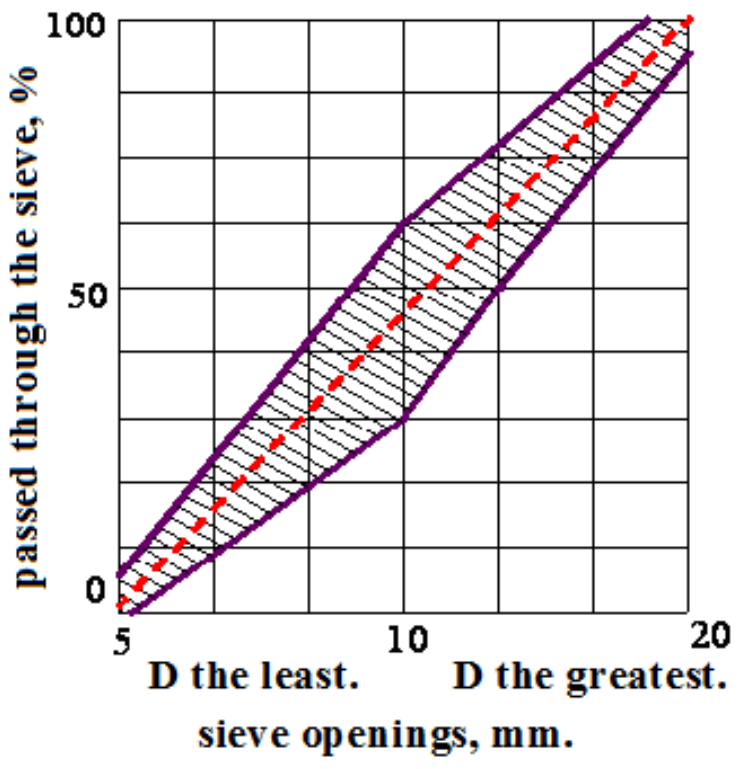

Fig. 2. Graph of crushed stone sifting

Technical data of GLENIUM 27S: Raw material base-polycarboxylate; color and form of delivery - brown liquid; density (at $20^{\circ} \mathrm{C}$ ) $1.10 \pm 0.02 \mathrm{~g} / \mathrm{cm}^{3} \mathrm{pH}-6.4 \pm 1.0$; chloride content $<0.1 \%$ by mass Alkali content $<3.0 \%$ by mass, ( $\mathrm{Na}_{2} \mathrm{O}$ equivalent)

Master X-Seed 100 (X-SEED 100), a unique cement-hardening accelerator - a core component of the Crystal Speed Hardening TM concept of application Master X-Seed 100 is a suspension of active nanoparticles designed to accelerate the process of cement hydration in the early stages (6-12 hours). It is based on the unique, innovative technology Crystal Speed Hardening ${ }^{\text {TM }}$ for accelerating crystallization. Significantly accelerates the growth of calcium hydrosilicate crystals. Master X-Seed 100, owing to unique technology, forms additional centers of crystallization of hydrosilicates of calcium between the cement grains, which significantly accelerates the development of early strength until the final microstructure reaches similar or improved characteristics. Crystal Speed Hardening TM concept Master X-Seed 100 is a core component of BASF's Crystal Speed Hardening ${ }^{\text {TM }}$ concept.

\section{Results and Discussion}

In the study of cement-sand compositions, it was stated that the optimal dosage of additives is $1 \%$ Glenium $27 \mathrm{~S}$ and $1.2 \%$ hardening accelerator Master X-Seed 100 . In the study, concrete samples were heat-treated according to the following scheme: 1 hour aging at a temperature $+28^{\circ} \mathrm{C}, 3$ hours of raising the temperature to $+40^{\circ} \mathrm{C}, 6$ hours of aging at that temperature and 2.5 hours of lowering the temperature. The results obtained are presented in Table 3. 
Table 3. Concrete strength after 12 hours of hardening

\begin{tabular}{|c|c|c|c|c|c|}
\hline \multirow[t]{2}{*}{ № } & \multicolumn{4}{|c|}{ Composition } & \multirow{2}{*}{$\begin{array}{c}\text { Strength of } \\
\text { concrete after } \\
12 \text { hours, MPa }\end{array}$} \\
\hline & $\begin{array}{l}\text { Amount and } \\
\text { type of additive }\end{array}$ & Type of cement & $\mathrm{W} / \mathrm{C}$ & $\begin{array}{l}\text { Mobility, } \\
\text { sec. }\end{array}$ & \\
\hline 1. & $\begin{array}{l}1 \% \text { Glenium } 27 \\
\text { S }\end{array}$ & $\begin{array}{c}\text { Portland cement } \\
\text { Akhangaran grade } 400 \text { D0 }\end{array}$ & 0.3 & $10-12$ & 34.5 \\
\hline 2. & $\begin{array}{l}1 \% \text { Glenium } 27 \\
\text { S }\end{array}$ & $\begin{array}{c}\text { Portland cement } \\
\text { Akhangaran grade } 400 \\
\text { D20 }\end{array}$ & 0.3 & $10-12$ & 34 \\
\hline 3. & $\begin{array}{c}1 \% \text { Glenium } 27 \\
\text { S and } 1.2 \% \\
\text { Master X-Seed } \\
100\end{array}$ & $\begin{array}{c}\text { Portland cement } \\
\text { Akhangaran grade } 400 \text { D0 }\end{array}$ & 0.26 & $10-13$ & 44.7 \\
\hline 4. & $\begin{array}{c}1 \% \text { Glenium } 27 \\
\text { S and } 1.2 \% \\
\text { Master X-Seed } \\
100\end{array}$ & $\begin{array}{c}\text { Portland cement } \\
\text { Akhangaran grade } 400 \\
\text { D20 }\end{array}$ & 0.26 & $10-13$ & 44.2 \\
\hline
\end{tabular}

The results given in Table 1 show that the samples after heat treatment at $40^{\circ} \mathrm{C}$ after 12 hours of hardening with $1 \%$ Glenium $27 \mathrm{~S}$ and 1.2\% Master X-Seed 100 have a strength of 44.7 MPa; and 44.2 MPa.

In further studies, the nature of the change in the strength of concrete was studied in the interval of $10 \ldots 14$ hours of hardening after thermal-moisture treatment. The results are shown in Fig.3.

From Fig.3. it can be seen that the obtained strength of concretes with additives after 12 hours of hardening is sufficient to transfer the prestress $(41 \mathrm{MPa})$ to concrete; therefore, compositions with $1 \%$ Glenium $27 \mathrm{~S}$ and 1.2\% Master X-Seed 100 can be used to obtain high-strength concrete.

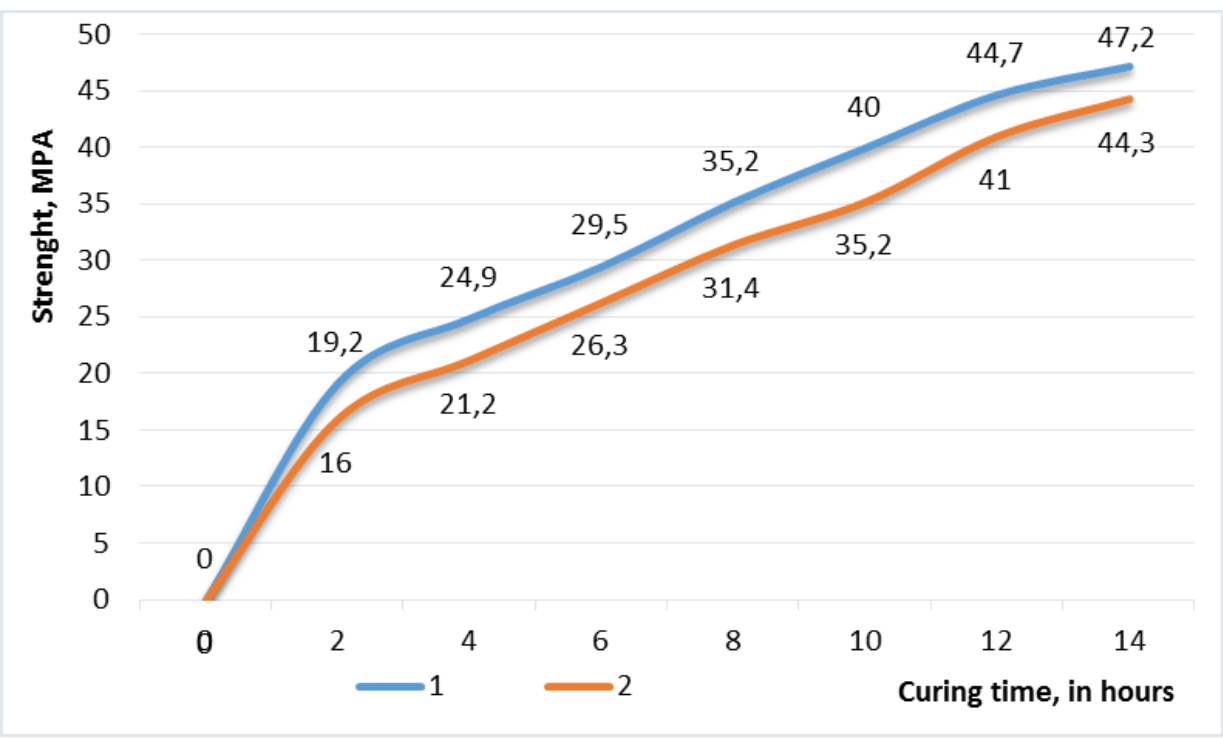

Fig. 3. Kinetics of strength growth of concrete with a complex additive after heat-moisture treatment: 1 is $1 \%$ Glenium $27 \mathrm{~S}$ and 1.2\% Master X-Seed 100, Portland cement Akhangaran grade 400 D0. 2 is Glenium 27 S and 1.2\% Master X-Seed 100, Portland cement Akhangaran grade 400 D20. 


\section{Conclusions}

1. From Figure 3. it can be seen that the obtained strength of concretes with additives after 12 hours of hardening is sufficient to transfer the prestress (41 $\mathrm{MPa})$ to concrete; therefore, compositions with $1 \%$ Glenium $27 \mathrm{~S}$ and $1.2 \%$ Master X-Seed 100 can be used to obtain high-strength concrete.

2. Thus, laboratory studies show the advantage of using the method of manufacturing concrete and reinforced concrete products with additives. It can also be used to manufacture other concrete and reinforced concrete products and structures, for example, tubing tunnels, piles, posts, lintels, crossbars, floor slabs, etc.

\section{References}

1. Petrova T.M., Serenko A.F., Egorov V.N. Resource-saving technologies in the manufacture of sleepers // Railways and track facilities, № 9. p. 2-3, (2006)

2. Serenko A.F. On improving the technology of production of reinforced concrete sleepers // Bulletin of the Petersburg University of Railways, № 1, p. 107-111, (2006)

3. Batrakov V.G. Modified concrete, p. 768 Moscow, (1998)

4. Petrova T.M., Vikhno E.V., Dzhashi N.F., Serenko A.F., Opaschko D.Y. The energysaving technology in production of prestressed reinforced concrete, International Conference on Building materials (16. ibausil), Tagungsbericht, p. 2-15. Weimar (Germany)

5. Technological instruction for the production of concrete and mortar mixtures in the BSU SB-75 at the MO-67 concrete and reinforced concrete structures production site. TI 1384801-04-2006.

6. Bazhenov Y.M. High-strength concrete with chemical additives, Concrete and reinforced concrete, № 8. pp. 29-31, (1977)

7. Kuntsevich O.V., Popova O.S. The use of water-soluble resins as additives to concrete / / Concrete and reinforced concrete, № 7, pp. 12-13, (1987)

8. Batrakov V.G., Issers F.A., Serykh R.L., Furmanov E.I. Properties of fine-grained mixtures and concretes with the addition of superplasticizers // Concrete and reinforced concrete. № 10, pp. 22-24, (1982)

9. The use of superplasticizers in concrete. Survey information. - VNIIMS Gosstroy USSR, p.58, (1982)

10. Ramachandran V. Additives to concrete: A reference guide, p. 575. Moscow, (1988)

11. Batrakov V.G., Sobolev K.G., Kaprielov S.S., Silina E.S., Zhigulev N.F. Highstrength low-cement concretes Chemical additives and their application in precast concrete production technology. Centre. Grew up. House of Knowledge, pp. 83-87, Moscow, (1992)

12. Bazhenov Y.M., Babaev Sh.T., Gruz A.I. and others. High-strength concrete based on superplasticizers, Building materials, № 9, pp. 21-24, (1988)

13. Akhverdov I.P. and other Properties of concrete with the addition of M-1 / Technology of concrete and composite materials, p. 50. Minsk, (1983)

14. A.A. Babin Concrete with a semi-functional superplasticizer based on light pyrolysis resin // Diss. Cand. Tech. Science. p. 137. Belgorod, (2009)

15. Turgunbaev U.J., Umirova M. On the technology of obtaining reinforced concrete sleepers by heating concrete at low temperatures, Vestnik TashIIT Special issue, pp. 109-115, (2020)

16. Batrakov V.G. Modified concrete. Theory and practice, p.768. Moscow, Higher school, (1998) 
17. Deutscheva M. Qualitatsverbesserung eines Zementgebundenen Feuerbetones aurch Einsatz eines Superplastifikators. "5 Symp. Feuer -" beton, Dresden, Apr. 13-15, (1987)

18. Hattory K., Experiences with Mighty Superplasticizers in Japan, Superplasticizers in Concrete, Amer. Concr. Jnst. SP-62, pp. 37-66 (1979).

19. Solomatov V.I., Takhirov M.K., Korotin M.M. Concrete with ACF additive for transport construction. - Moscow, Transport, (1986)

20. Ratinov V.B., Ivanov F.M. Chemistry in construction, p. 220, Moscow, Stroyizdat, (1977)

21. Ivanov F.M., Batrakov V.G., Silina E.S., Fainer M.Sh. Superplasticizer for obtaining high-quality concretes // Industrial construction and engineering structures, № 4, pp. 34-35, (1980) 